\title{
Enzyme-Based Test Strips for Visual and Photographic Detection and Quantitation of Gaseous Sulfur Mustard
}

\author{
Sarka Bidmanova, Mark-Steven Steiner, Martin Stepan, Kamila Vymazalova, Michael A. Gruber, \\ Axel Dürkop, Jiri Damborsky, Zbynek Prokop, Otto S. Wolfbeis
}

\section{Contents}

\section{Introduction}

Existing techniques

Table S-1. Overview of analytical techniques suitable for on-site detection of gaseous sulfur mustard. Table S-2. Comparison of properties of sulfur mustard and its non-blistering analogue.

\section{Experimental section}

Selection of immobilization procedures for the LinB enzyme

Cross-linked enzyme mixed with D4 hydrogel

Cross-linked enzyme aggregates mixed with D4 hydrogel

Cross-linking of enzyme on D4 hydrogel layer

Table S-3. Composition of immobilization mixture and time of cross-linking with glutaraldehyde.

Optimization of immobilization for LinB enzyme

Evaluation of the immobilization for LinB enzyme

Preparation of gaseous analytes

Bis(2-chloroethyl) ether and interfering chemicals

Sulfur mustard

Figure S-1. Experimental set-up used for the exposure of test strips to gaseous sulfur mustard during calibration.

\section{Results and discussion}

Performance of test strips

Figure S-2. Effect of the buffer used for hydration on the performance of the test strips.

Table S-4. Effect of interferents on the response of the test strips using statistics.

Table S-5. Reproducibility of the response of the test strips towards gaseous bis(2-chloroethyl) ether.

Figure S-3. Effect of storage and freezing and thawing on the response of the test strips to gaseous bis(2-chloroethyl) ether.

Table S-6. Relative standard deviations calculated for the strip response to bis(2-chloroethyl) ether.

Table S-7. Effect of storage and freezing and thawing on the response of the test strips using statistics.

Figure S-4. Effect of temperature on the response of the test strips to gaseous bis(2-chloroethyl) ether.

Table S-8. Effect of temperature on the response of the test strips using statistics.

Table S-9. Comparison of the response of enzymatic and non-enzymatic strips to gaseous sulfur mustard using statistics.

\section{References}




\section{Introduction}

Table S-1. Overview on commonly used analytical techniques for on-site detection of gaseous sulfur mustard (SM). Main techniques include colorimetry, ion mobility spectrometry, flame emission spectrometry, infrared spectroscopy, surface acoustic wave sensing, gas chromatography and mass spectrometry, sometimes hyphenated. All have certain merits and limitations. Table S-2 summarizes characteristic physico-chemical properties of $\mathrm{SM}$ and its non-blistering analogue. The features of the test strips described here are given in red.

\begin{tabular}{lll}
\hline $\begin{array}{l}\text { Analytical } \\
\text { method }\end{array}$ & Principle & Advantages $^{1-4}$ \\
\hline Colorimetry & $\begin{array}{l}\text { Detection tubes and papers } \\
\text { based on a color change as a } \\
\text { result of specific chemical } \\
\text { reaction that occurs when } \\
\text { analyte interacts with certain } \\
\text { substrate }\end{array}$ & $\begin{array}{l}\text { High specificity (tubes) } \\
\text { Simplicity of use }\end{array}$ \\
& $\begin{array}{l}\text { Low-costs } \\
\text { Portability }\end{array}$ \\
& Detection of both gases (tubes) and droplets \\
& (papers) \\
& Convenient for initial screening
\end{tabular}

Ion mobility spectrometry

Flame emission spectrometry
Radioactive ionization of a sample followed by separation of ions according to their mass to charge ratio as they move through a gas in an electric field

Atomic spectroscopy based on the light emission of excited atoms or clusters as they return to lower energy states

\section{High sensitivity}

Fast response time

Simplicity with minimal training

No sample preparation

Portable; no external power supply needed, carrier gases or vacuum pump required

Very specific and sensitive to organosulfur and/or organophosphorus compounds

Relatively large linear detection range Real-time detection

No sample preparation, no toxic waste Simple maintenance

Hyphenation with gas chromatograph possible

\section{Disadvantages}

Lack of specificity (papers)

Slow response time 15-20 min

Field application of a broad set of tubes due to selectivity

Requires air pump (tubes) and heating at low temperature

Effect of flow rate and moisture on response

Problematic visual evaluation due to dim or bright light and color blindness

False positives in the presence of sodium hydroxide or petroleum products (papers)

False positives from complex mixtures

Limitation of quantitative detection by non-linear signal of detector

Resolving power 1-2 orders of magnitude below that of mass spectrometry

Unpredictable maintenance intervals

Detector warm up from a few min to $30 \mathrm{~min}$

Significant effect of temperature, pressure and humidity on detector performance

Expensive instrumentation

Prone to false positives from exhausts, fuel spills and detergents

Semiselectivity - response to all substances containing sulfur and/or phosphorus

Hindrance in long-term operation by requirement for hydrogen gas 


\section{Portability}

Infrared

spectroscopy

Surface acoustic wave sensing

\section{Gas}

chromatography mass spectrometry
Spectrum after absorption of infrared radiation creates an unique molecular fingerprint

Change of amplitude or phase of acoustic wave generated by application of a time-varying electric field to a piezoelectric material as a result of specific adsorption of analyte on polymer-coated surface

Separation of gas-phase ions according to mass to charge ratio
Real-time detection

Fast response time

Minimal sample preparation

High sensitivity

Fast response time

Small size and portability

Effective detection under a variety of conditions

High sensitivity

High selectivity

High accuracy

Possibility of identification and quantification of analytes
Sensitivity not sufficient

Determination of known analyte, not identification

High costs

Complexity and size of instrumentation

Effect of humidity on detector performance

False positives and negatives due to polymer absorption ability

Need of preconcentrator for low concentrations

Recovery time of polymer up to several min

Effect of temperature and humidity on detector performance

Susceptibility to damages from some highly reactive vapors

Unpredictable operation time

Time-consuming sample preparation and analysis

Expensive and complex instrumentation

Non-continuous detection

Difficult operation and maintenance on a routine basis

Difficult operation in field without support of a fully mobile laboratory

\section{Colorimetry}

Test strips based on a color

change as a result of specific

enzymatic reaction that occurs

after interaction with analyte

\section{Simplicity of use}

Low-costs

Fast response time

No sample preparation

Portability, no external power supply needed

Convenient for initial screening
Lower sensitivity

Effect of temperature on performance

Problematic visual evaluation due to dim or bright light and color blindness

Requirement on simultaneous use of enzymatic and nonenzymatic strips to exclude false positives 
Table S-2. Comparison of properties of SM and its non-blistering analogue BCEE. ${ }^{5-7}$

\begin{tabular}{|c|c|c|}
\hline Properties & Sulfur mustard (SM) & Bis(2-chloroethyl) ether (BCEE) \\
\hline Structural formula & & \\
\hline Physical state & Oily liquid & Liquid \\
\hline Appearance & Colorless ${ }^{\mathrm{a}}$ & Colorless \\
\hline Odour & Sweet, garlic or horseradish-like & Pungent, chlorinated solvent-like \\
\hline Molecular weight & 159.08 & 143.02 \\
\hline Boiling point $\left({ }^{\circ} \mathrm{C}\right)$ & $215-217$ & 178.50 \\
\hline Freezing point $\left({ }^{\circ} \mathrm{C}\right)$ & 13.50 & -51.90 \\
\hline Density $\left(\mathrm{g} / \mathrm{cm}^{3}, 20^{\circ} \mathrm{C}\right)$ & 1.27 & 1.22 \\
\hline Vapor pressure $\left(\mathrm{mm} \mathrm{Hg}, 25^{\circ} \mathrm{C}\right)$ & 0.11 & 0.40 \\
\hline Solubility in water $\left(\mathrm{g} / \mathrm{L}, 20^{\circ} \mathrm{C}\right)$ & 0.80 & 10.20 \\
\hline Solubility in organic solvents & Acetone, diethyl ether, tetrachloroethane & Ethanol and diethyl ether \\
\hline $\mathrm{pH}$ value & Neutral, slowly turns acidic during storage & Neutral \\
\hline Vesicant action & Blistering agent & Non-blistering agent \\
\hline
\end{tabular}




\section{Experimental section}

Selection of immobilization procedures for the LinB enzyme

Cross-linked enzyme mixed with D4 hydrogel. The LinB enzyme (lyophilized in $50 \mathrm{mM}$ phosphate buffer, $\mathrm{pH} 7.5,4.4 \mathrm{mg}$ ) and powder of bovine serum albumin (BSA, $8.9 \mathrm{mg}$ ) were dissolved in $50 \mu \mathrm{L}$ of water. Glutaraldehyde $(0.5 \mathrm{wt} \%$ in water, $10 \mu \mathrm{L})$ was added to $45 \mu \mathrm{L}$ of dissolved proteins. The mixture was gently shaken for $1 \mathrm{~h}$ at $23{ }^{\circ} \mathrm{C}$. Cross-linked proteins were mixed with $200 \mu \mathrm{L}$ of HydroMed D4 hydrogel. The mixture ( $30 \mu \mathrm{L}$ per strip) was spread onto the neutral and alkaline $\mathrm{pH}-$ sensitive panels of the strips using a knife-coating device. The thickness of the final hydrogel layer was $125 \mu \mathrm{m}$ and it was air-dried for $1 \mathrm{~h}$ at $23{ }^{\circ} \mathrm{C}$.

Cross-linked enzyme aggregates (CLEAs) mixed with D4 hydrogel. The LinB enzyme (lyophilized in $50 \mathrm{mM}$ phosphate buffer, $\mathrm{pH} 7.5,38.4 \mathrm{mg}$ ) and BSA (38.4 mg) were dissolved in $9.6 \mathrm{~mL}$ of water and precipitated by $28.8 \mathrm{~mL}$ of saturated ammonium sulfate $(\mathrm{pH} 8.0)$ for 45 min under stirring. Precipitated proteins were cross-linked with $3.1 \mathrm{~mL}$ of dextran polyaldehyde ${ }^{8}$ for $45 \mathrm{~min}$. Precipitation and cross-linking steps were performed in an ice bath. After cross-linking, the suspension was centrifuged at $4,000 \mathrm{~g}$ for $20 \mathrm{~min}$ at $4{ }^{\circ} \mathrm{C}$. The supernatant was withdrawn and resulting CLEAs were resuspended in $30.7 \mathrm{~mL}$ of saturated sodium hydrogen carbonate. Sodium borohydride $(61.4 \mathrm{mg})$ was added to the solution and was allowed to react for $30 \mathrm{~min}$ at $4{ }^{\circ} \mathrm{C}$ under stirring. CLEAs were washed three times with $50 \mathrm{mM}$ phosphate buffer $(\mathrm{pH} 7.5)$ and separated by centrifugation at $4,000 \mathrm{~g}$ for $20 \mathrm{~min}$ at $4{ }^{\circ} \mathrm{C}$. Resuspended CLEAs were carefully mixed with HydroMed D4 hydrogel to prepare 20, 30 and 35\% (v/v) solution of CLEAs. The mixture $(50 \mu \mathrm{L}$ per strip) was spread onto the neutral and alkaline $\mathrm{pH}$-sensitive panels of the strips using a knife-coating device. The thickness of the final hydrogel layer was $125 \mu \mathrm{m}$ which was air-dried for $1 \mathrm{~h}$ at $23{ }^{\circ} \mathrm{C}$.

Cross-linking of enzyme on D4 hydrogel layer. HydroMed D4 hydrogel was spread onto the pHsensitive panels of the strips using a knife-coating device ( $50 \mu \mathrm{L}$ of hydrogel per strip). The thickness of the layer was $125 \mu \mathrm{m}$. The hydrogel was allowed to dry for $1 \mathrm{~h}$ at $23{ }^{\circ} \mathrm{C}$. The LinB enzyme (lyophilized in $50 \mathrm{mM}$ phosphate buffer, $\mathrm{pH} 7.5,50 \mathrm{mg}$ ) and BSA $(100 \mathrm{mg})$ were dissolved in a ratio of 1:2 or 1:4 (w/w) in water (Table S-3). Immobilization mixture (10 $\mu \mathrm{L}$ per strip) was spread onto the neutral and alkaline $\mathrm{pH}$-sensitive panel of the strips using a pipette. The strips were exposed to glutaraldehyde vapors for 30 or $60 \mathrm{~min}$.

Table S-3. Composition of immobilization mixture and time of cross-linking with glutaraldehyde.

\begin{tabular}{lllll}
\hline $\begin{array}{l}\text { Ratio LinB:BSA } \\
(\mathbf{w} / \mathbf{w})\end{array}$ & $\begin{array}{l}\text { LinB enzyme } \\
(\mathbf{m g})\end{array}$ & $\begin{array}{l}\text { BSA } \\
(\mathbf{m g})\end{array}$ & $\begin{array}{l}\text { Deionized water } \\
(\boldsymbol{\mu L})\end{array}$ & $\begin{array}{l}\text { Cross-linking } \\
\text { time }(\mathbf{m i n})\end{array}$ \\
\hline $1: 2$ & 10 & 20 & 160 & 30 \\
$1: 2$ & 10 & 20 & 160 & 60 \\
$1: 4$ & 8 & 32 & 160 & 30 \\
\hline
\end{tabular}

Optimization of immobilization for LinB enzyme

The immobilization mixture was prepared by dissolving LinB enzyme (lyophilized in $50 \mathrm{mM}$ phosphate buffer, $\mathrm{pH}$ 7.5) and BSA in a ratio of 1:2 (w/w) in water (Table S-3). Different amounts of immobilization mixture $(10,20,30$ and $40 \mu \mathrm{L}$ corresponding to $0.9,2.0,2.9$ and $3.8 \mathrm{mg}$ of $\mathrm{LinB}$ enzyme per $\mathrm{cm}^{2}$ ) were spread onto the neutral and alkaline $\mathrm{pH}$-sensitive panels of the strip using a pipette. The immobilization mixture was applied on the strips stepwise (increments of $10 \mu \mathrm{L}$ of immobilization mixture). Every addition was followed by a drying period of $10 \mathrm{~min}$. The resulting strips were exposed to glutaraldehyde vapor for $30 \mathrm{~min}$. Immobilized enzyme was found in three different arrangements depending on how the hydrogel was applied, viz., as an upper layer, a sandwich, and a bottom layer. The thickness of the hydrogel layer spread via the knife-coating device was $125 \mu \mathrm{m}$. The layer was always allowed to dry for $1 \mathrm{~h}$ on air at $23^{\circ} \mathrm{C}$. 
Evaluation of the immobilization for LinB enzyme

The immobilization was assessed by measurement of an enzymatic activity and by visual evaluation of a $\mathrm{pH}$ change on the strips. The test strips were exposed to $10 \mathrm{~mL}$ of a $100 \mathrm{mM}$ glycine buffer $(\mathrm{pH}$ 8.6) for $0.5 \mathrm{~h}$ at $23{ }^{\circ} \mathrm{C}$ before measurement of activity. Enzymatic activity was assessed in $10 \mathrm{~mL}$ of $100 \mathrm{mM}$ glycine buffer ( $\mathrm{pH}$ 8.6) at $23{ }^{\circ} \mathrm{C}$ using the Iwasaki method. ${ }^{9}$ As a substrate, $10 \mu \mathrm{L}$ of BCEE were added to the buffer. The reaction was started by addition of free or immobilized enzyme to the reaction mixture and terminated by mixing with $35 \%$ (v/v) nitric acid. Increasing concentrations of the reaction products were measured spectroscopically with mercuric thiocyanate and ferric ammonium sulfate at $450 \mathrm{~nm}$ (FLUOstar OPTIMA, BMG Labtech, Germany). The amount of reaction products was determined from a calibration curve prepared using sodium chloride as a standard solution.

The $\mathrm{pH}$ change accompanying the enzymatic reaction was evaluated visually by comparison of the enzymatic strip with a reference color scale. The performance of the test strips was documented using a digital camera (Canon PowerShot A700, Japan). The camera operated in automatic mode with macroimaging setting. Photographs of the strips were taken immediately after preparation and hydration of the strips (time $0 \mathrm{~min}$ ) and after exposure of strips to an analyte (time $10 \mathrm{~min}$ ).

\section{Preparation of gaseous analytes}

BCEE and interfering chemicals. BCEE, 1,2-dichloroethane and ethyl bromoacetate were diluted to required concentrations using methanol. The mixture $(5 \mu \mathrm{L})$ was injected into an airtight vial (volume of $20 \mathrm{~mL}$ ) and allowed to evaporate for $30 \mathrm{~min}$ at $23{ }^{\circ} \mathrm{C}$. Subsequently, the test strips were exposed to gaseous analytes by insertion into the vial. Gaseous concentrations of analytes were determined using gas chromatograph coupled with a mass spectrometer (Trace MS 2000, Finnigan, USA).

$S M$. The gaseous analyte was prepared by taking a fresh aliquot of SM from the pure compound to minimize the possible risk of hydrolysis. Two different experimental set-ups were used for the exposure of test strips to SM: $(i)$ In the first, the test strips were fixed with a clamp and exposed to saturated vapors of SM. The vapors were produced by reaching equilibrium from a volatile liquid in a closed system, the concentration of saturated vapors was adopted from table values. ${ }^{7}$ (ii) The second relates to the calibration of test strips which was performed in a stream of air containing gaseous SM (Figure S-1).

Figure S-1. Experimental set-up used for the exposure of test strips to gaseous SM during calibration.

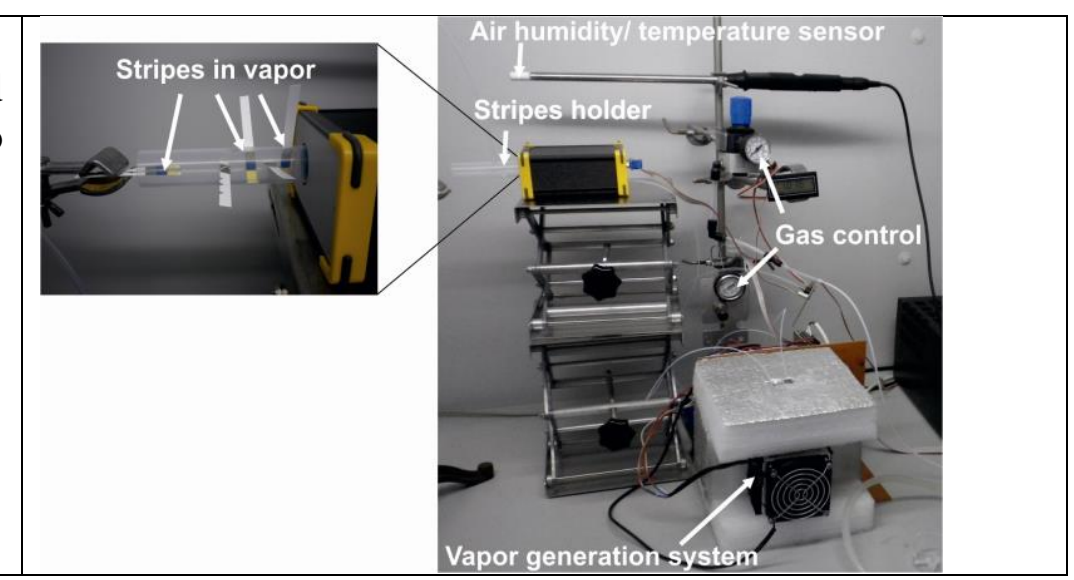

Vapors of SM were generated by evaporating $0.5 \mathrm{~mL}$ of the pure compound in a teflon vessel by increasing the temperature in a vapor generation system (Military Research Institute; Czech Republic). Nitrogen gas was pumped through the vessel after system stabilization and pushed the mustard vapors into home-made holder of the strips. The experiments were performed at ambient temperature and humidity which were monitored with a combined air humidity/ temperature meter. The real concentration of the gaseous analyte was verified at the beginning of each measurement. The vapors $(1.3 \mathrm{~L})$ were drawn through a bilayer tenax adsorption tube $(8 \times 110 \mathrm{~mm}$; SKC; USA). Subsequently, thermal desorption was followed by analysis using a gas chromatograph coupled to a mass spectrometer (EM640 GC-MS; Bruker; Germany). 


\section{Results and discussion}

Performance of test strips

Figure S-2 shows the effect of the buffer used for hydration on the performance of the test strips. The strips were incubated in: $100 \mathrm{mM}$ glycine buffer ( $\mathrm{pH} 8.6$, red squares), $50 \mathrm{mM}$ borate buffer ( $\mathrm{pH} 8.6$,

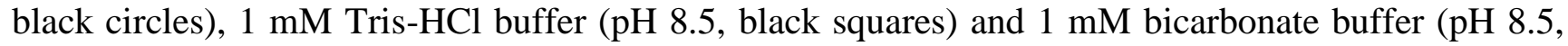
black triangles) for $20 \mathrm{~min}$. The response of strips to gaseous BCEE at $23{ }^{\circ} \mathrm{C}$ was evaluated using the RGB readout. The signal of the non-enzymatic strip (control) was subtracted from the signal of the enzymatic strip. The standard deviations were calculated from two to four independent measurements $(2 \leq n \leq 4)$. Table $\mathbf{S}-\mathbf{4}$ gives statistical data on the effect of interferents on the strip response. Table S-5 gives data on the reproducibility of the strip response to gaseous BCEE.

Figure S-2. Effect of the buffer used for hydration on the performance of the test strips.

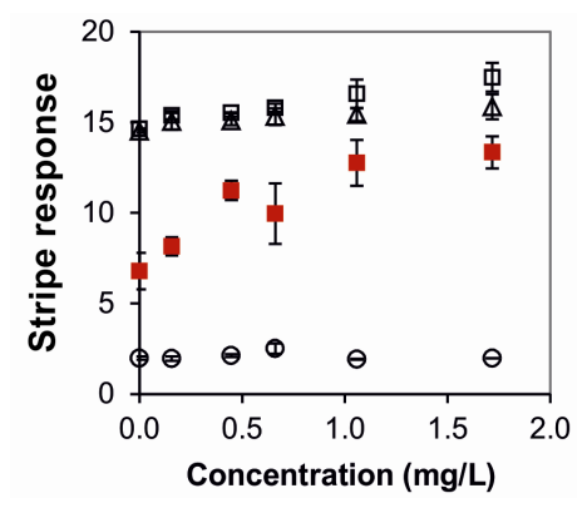

Table S-4. The effect of interferents on the strip response $(n=3)$ at $23{ }^{\circ} \mathrm{C}$. The response was evaluated after 10 min using RGB readout.

\begin{tabular}{|c|c|c|c|c|c|c|c|c|}
\hline Analyte & $\begin{array}{l}\text { Conc. } \\
(\mathrm{mg} / \mathrm{L})\end{array}$ & Strip & Mean & SD & SEM & $\begin{array}{l}\text { MD } \\
\text { (CI) }\end{array}$ & $p$ value & $\begin{array}{l}\text { Signifi- } \\
\text { cance }\end{array}$ \\
\hline \multirow[t]{2}{*}{ BCEE } & \multirow[t]{2}{*}{7.1} & $\mathrm{E}$ & 17.0626 & 0.4279 & 0.1914 & \multirow{2}{*}{$\begin{array}{l}14.0895 \\
(13.5260 ; 14.6766)\end{array}$} & \multirow{2}{*}{$<0.0001$} & \multirow{2}{*}{ SS } \\
\hline & & $\mathrm{NE}$ & 2.9730 & 0.2746 & 0.1373 & & & \\
\hline \multirow{2}{*}{$\begin{array}{l}1,2- \\
\text { Dichloroethane }\end{array}$} & \multirow[t]{2}{*}{6.3} & $\mathrm{E}$ & 2.8247 & 0.4430 & 0.2557 & \multirow{2}{*}{$\begin{array}{l}0.8402 \\
(-0.2310 ; 1.9113)\end{array}$} & \multirow{2}{*}{0.088} & \multirow{2}{*}{ NSS } \\
\hline & & $\mathrm{NE}$ & 1.9845 & 0.1242 & 0.0878 & & & \\
\hline \multirow{2}{*}{$\begin{array}{l}1,2- \\
\text { Dichloroethane } \\
+ \text { BCEE }\end{array}$} & 6.9 & $\mathrm{E}$ & 18.2720 & 0.7433 & 0.4292 & \multirow{2}{*}{$\begin{array}{l}15.7265 \\
(13.9591 ; 17.4938)\end{array}$} & \multirow{2}{*}{$<0.0001$} & \multirow{2}{*}{ SS } \\
\hline & 6.8 & $\mathrm{NE}$ & 2.5455 & 0.0720 & 0.0509 & & & \\
\hline \multirow{2}{*}{$\begin{array}{l}1,2- \\
\text { Dichloroethane } \\
+ \text { BCEE }\end{array}$} & 3.4 & E & 16.3515 & 0.1641 & 0.0947 & \multirow{2}{*}{$\begin{array}{l}13.3815 \\
(12.7156 ; 14.0473)\end{array}$} & \multirow{2}{*}{$<0.0001$} & \multirow{2}{*}{ SS } \\
\hline & 7.4 & $\mathrm{NE}$ & 2.9700 & 0.3816 & 0.2203 & & & \\
\hline \multirow{2}{*}{$\begin{array}{l}\text { Ethyl bromo- } \\
\text { acetate }\end{array}$} & \multirow[t]{2}{*}{6.2} & E & 16.1038 & 0.9634 & 0.5562 & \multirow{2}{*}{$\begin{array}{l}-0.5742 \\
(-2.9260 ; 1.7775)\end{array}$} & \multirow{2}{*}{0.4938} & \multirow{2}{*}{ NSS } \\
\hline & & $\mathrm{NE}$ & 16.6781 & 0.3309 & 0.2340 & & & \\
\hline \multirow{2}{*}{$\begin{array}{l}\text { Ethyl bromo- } \\
\text { acetate + BCEE }\end{array}$} & 6.7 & E & 16.2994 & 0.5816 & 0.3358 & \multirow{2}{*}{$\begin{array}{l}10.9427 \\
(9.5353 ; 12.3501)\end{array}$} & \multirow{2}{*}{0.0001} & \multirow{2}{*}{ SS } \\
\hline & 9.4 & $\mathrm{NE}$ & 5.3567 & 0.1657 & 0.1172 & & & \\
\hline \multirow{2}{*}{$\begin{array}{l}\text { Ethyl bromo- } \\
\text { acetate + BCEE }\end{array}$} & 2.8 & $\mathrm{E}$ & 17.25 & 0.2240 & 0.1293 & \multirow{2}{*}{$\begin{array}{l}12.3186 \\
(11.7868 ; 12.8504)\end{array}$} & \multirow{2}{*}{$<0.0001$} & \multirow{2}{*}{ SS } \\
\hline & 9.8 & $\mathrm{NE}$ & 4.9286 & 0.0148 & 0.0104 & & & \\
\hline
\end{tabular}


Abbreviations: CI - 95\% confidence interval of mean of difference, Conc. - concentration of analyte, E enzymatic strip, MD - mean of difference of enzymatic minus non-enzymatic strips, NE - non-enzymatic strip, NSS - difference considered to be not statistically significant, SD - standard deviation, SEM - standard error of the mean, SS - difference considered to be statistically significant

Table S-5. Reproducibility of the response of test strips towards gaseous BCEE (concentration of $7.1 \mathrm{mg} / \mathrm{L})$ at $23{ }^{\circ} \mathrm{C}$. Samples were assayed in quintuplicate per day over 3 days $(n=5)$.

\begin{tabular}{|c|c|c|c|c|c|c|}
\hline & \multicolumn{3}{|c|}{ Intra-assay $^{a}$} & \multicolumn{3}{|c|}{ Inter-assay $^{b}$} \\
\hline Strip response/day & 14.91 & 14.54 & 15.14 & 14.91 & 17.06 & 15.61 \\
\hline $\mathrm{SD} /$ day & 0.13 & 0.46 & 0.13 & 0.13 & 0.38 & 0.67 \\
\hline Mean of strip response & 14.86 & & & 15.86 & & \\
\hline SD of mean & 0.24 & & & 0.90 & & \\
\hline RSD (\%) & 1.64 & & & 5.65 & & \\
\hline
\end{tabular}

Abbreviations: SD - standard deviation, RSD - relative standard deviation

${ }^{\mathrm{a}}$ Test strips prepared from one batch of enzyme and $\mathrm{pH}$ indicator strips. Assay performed on three different days using the same substrate mixture.

$\mathrm{b}$ Test strips prepared from three different batches of enzyme and $\mathrm{pH}$ indicator strips. Cross-linking was performed independently for each batch. Assay performed on three different days using a new substrate mixture.

The effect of storage (A) and freezing and thawing (B) on the response of the test strips to gaseous BCEE is shown in Figure S-3. The strips were exposed to $4.2 \mathrm{mg} / \mathrm{L}$ of BCEE at $23{ }^{\circ} \mathrm{C}$. (A) The strips were stored: at $4{ }^{\circ} \mathrm{C}$ (black squares), at $23{ }^{\circ} \mathrm{C}$ (black triangles), lyophilized and subsequently stored at $23{ }^{\circ} \mathrm{C}$ (red triangles). (B) The strips were frozen at $-21^{\circ} \mathrm{C}$, defrosted every day for $1 \mathrm{~h}$, three of them were assayed and the remaining were frozen again. The response in both tests was evaluated after 10 min using the RGB readout. The standard deviations were calculated from minimally three independent measurements $(n \geq 3)$.

Figure S-4 shows the effect of temperature on the response of the test strips to gaseous BCEE. The strips were exposed to BCEE at $23{ }^{\circ} \mathrm{C}$ (red squares) and $37{ }^{\circ} \mathrm{C}$ (black squares). The response in both tests was evaluated after $10 \mathrm{~min}$ using the RGB readout. The standard deviations were calculated from minimally two independent measurements $(n \geq 2)$.

Table S-6 gives relative standard deviations calculated for the strip response to BCEE $(4.2 \mathrm{mg} / \mathrm{L})$ at $23{ }^{\circ} \mathrm{C}(n=3)$. Table S-7 and Table S-8 give statistical data on the effect of storage, freezing and thawing and temperature on the response of test strips exposed to gaseous BCEE. Table $\mathbf{S}-\mathbf{9}$ gives statistical data on the response of enzymatic and non-enzymatic strips exposed to gaseous SM.

Figure S-3. Effect of (A) storage and $(\mathrm{B})$ freezing and thawing on the response of test strips to gaseous BCEE.
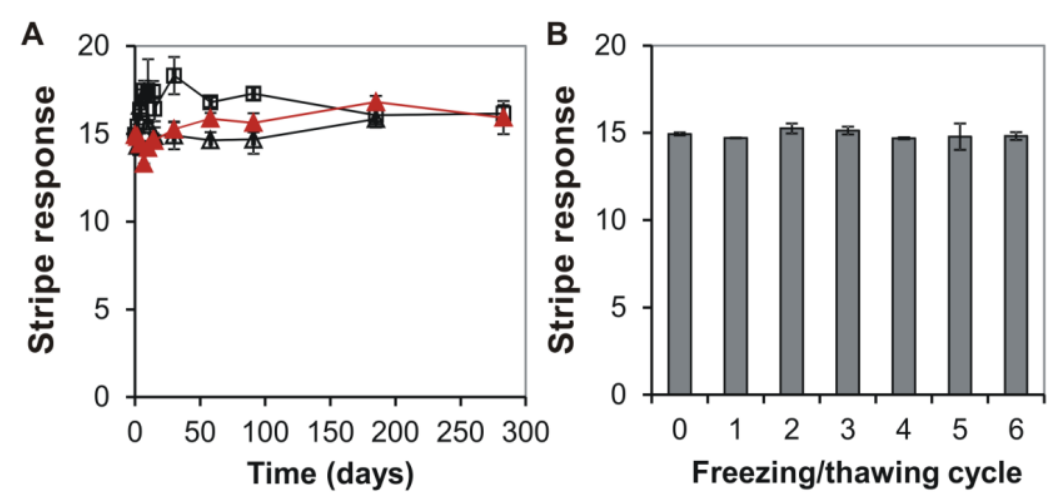
Table S-6. Relative standard deviations (\%) calculated for the strip response to BCEE (4.2 mg/L) at $23{ }^{\circ} \mathrm{C}$. The strips were stored at different storage conditions.

\begin{tabular}{llll}
\hline $\begin{array}{l}\text { Time } \\
\text { (days) }\end{array}$ & $\mathbf{4}^{\circ} \mathbf{C}$ & \multicolumn{2}{c}{ Storage conditions } \\
\hline 0 & 7.2 & $\mathbf{2 3}^{\circ} \mathbf{C}$ & Lyophilized, $23{ }^{\circ} \mathbf{C}$ \\
2 & 0.8 & 0.5 & 2.0 \\
4 & 1.5 & 1.5 & 7.0 \\
7 & 3.9 & 1.9 & 4.1 \\
10 & 12.2 & 1.7 & 0.1 \\
14 & 4.1 & 2.0 & 2.6 \\
15 & 4.7 & 3.3 & 2.7 \\
30 & 7.1 & 5.2 & 2.1 \\
58 & 1.8 & 3.0 & 2.7 \\
91 & 2.3 & 5.5 & 2.1 \\
185 & 3.5 & 3.2 & 3.6 \\
283 & 3.2 & n.d. & 2.4 \\
\hline
\end{tabular}

Abbreviations: n.d. not determined

Table S-7. Effect of storage and freezing and thawing on the response of strips $(n=3$ and $n=4$, respectively) exposed to gaseous BCEE. The strip response was evaluated after 10 min using RGB readout.

\begin{tabular}{|c|c|c|c|c|c|c|c|}
\hline Experiment & $\begin{array}{l}\text { Sample } \\
\text { group }\end{array}$ & Mean & SD & SEM & $\begin{array}{l}\text { MD } \\
\text { (CI) }\end{array}$ & $p$ value & Significance \\
\hline \multirow{5}{*}{ Storage } & Control & 14.9397 & 0.0639 & 0.0369 & - & - & - \\
\hline & $4{ }^{\circ} \mathrm{C}$ & 16.1496 & 0.6428 & 0.3711 & $\begin{array}{l}-1.2157 \\
(-2.7976 ; 0.3661)\end{array}$ & 0.0806 & NSS \\
\hline & $23^{\circ} \mathrm{C}$ & 15.8488 & 0.7273 & 0.5143 & -0.9113 & \multirow[t]{2}{*}{0.3275} & \multirow[t]{2}{*}{ NSS } \\
\hline & & & & & $(-7.4565 ; 5.6339)$ & & \\
\hline & Lyophilized & 15.9217 & 1.2300 & 0.7101 & $\begin{array}{l}-0.9887 \\
(-4.0278 ; 2.0520)\end{array}$ & 0.2969 & NSS \\
\hline \multirow{2}{*}{$\begin{array}{l}\text { Freezing and } \\
\text { thawing }\end{array}$} & $0^{\text {th }}$ cycle & 14.9396 & 0.1076 & 0.0538 & \multirow{2}{*}{$\begin{array}{l}0.1221 \\
(-0.2102 ; 0.4544)\end{array}$} & \multirow{2}{*}{0.4032} & \multirow{2}{*}{ NSS } \\
\hline & $6^{\text {th }}$ cycle & 14.8175 & 0.2494 & 0.1247 & & & \\
\hline
\end{tabular}


Abbreviations: CI - 95\% confidence interval of mean of difference, $\mathrm{MD}$ - mean of difference of control and stored strips or strips in cycle $0^{\text {th }}$ and $6^{\text {th }}$, NSS - difference considered to be not statistically significant, SD standard deviation, SEM - standard error of the mean

Figure S-4. Effect of the temperature on the performance of the test strips.

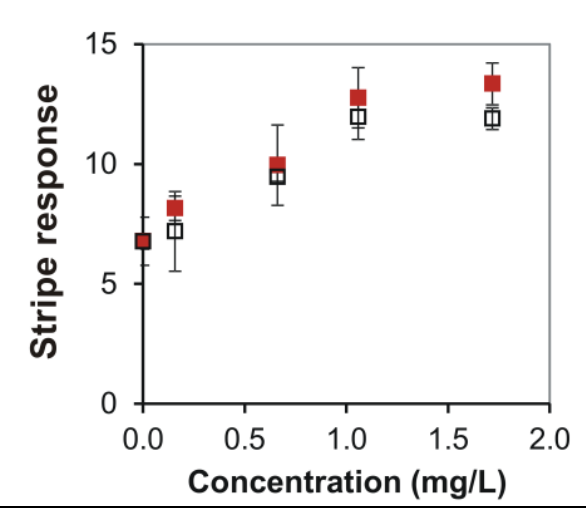

Table S-8. Effect of temperature on the response of strips $(n \geq 2)$ exposed to gaseous BCEE. The strip response was evaluated after 10 min using RGB readout.

\begin{tabular}{llllllll}
\hline $\begin{array}{l}\text { Conc. } \\
(\mathbf{m g} / \mathbf{L})\end{array}$ & $\begin{array}{l}\text { Temp. } \\
\left({ }^{\circ} \mathbf{C}\right)\end{array}$ & Mean & SD & SEM & $\begin{array}{l}\text { MD } \\
(\mathbf{C I})\end{array}$ & $\boldsymbol{p}$ value & Significance \\
\hline 0.2 & 23 & 8.1554 & 0.6224 & 0.3594 & 0.9656 & 0.5177 & NSS \\
& 37 & 7.1898 & 2.3468 & 1.6594 & $(-3.2384 ; 5.1696)$ & & \\
0.7 & 23 & 9.9587 & 2.0526 & 1.1851 & 0.4941 & 0.7688 & NSS \\
& 37 & 9.4646 & 0.2586 & 0.1829 & $(-4.3941 ; 5.3823)$ & & \\
1.1 & 23 & 12.7649 & 1.5472 & 0.8933 & 0.8018 & 0.5938 & NSS \\
& 37 & 11.9631 & 1.3231 & 0.9356 & $(-3.4870 ; 5.091)$ & & \\
1.7 & 23 & 13.3442 & 1.0756 & 0.6210 & 1.45 & & \\
& 37 & 11.8931 & 0.6210 & 0.4553 & $(-1.3194 ; 4.2217)$ & 0.1941 & NSS
\end{tabular}

Abbreviations: CI - 95\% confidence interval of mean of difference, Conc. - concentration of analyte, MD mean of difference of strips incubated at 23 and $37{ }^{\circ} \mathrm{C}$, NSS - difference considered to be not statistically significant, SD - standard deviation, SEM - standard error of the mean 
Table S-9. Comparison of the response of enzymatic and non-enzymatic strips using statistics. The strips $(n=3)$ were hydrated in $20 \%$ dioxane and exposed to gaseous SM at $24{ }^{\circ} \mathrm{C}$. The strip response was evaluated after 10 min using RGB readout.

\begin{tabular}{|c|c|c|c|c|c|c|c|}
\hline $\begin{array}{l}\text { Conc. } \\
(\mathrm{mg} / \mathrm{L})\end{array}$ & Strip & Mean & SD & SEM & $\begin{array}{l}\text { MD } \\
\text { (CI) }\end{array}$ & $p$ value & Significance \\
\hline \multirow[t]{2}{*}{2.8} & $\mathrm{E}$ & 3.0937 & 0.1230 & 0.0710 & \multirow{2}{*}{$\begin{array}{l}0.8197 \\
(0.4056 ; 1.2338)\end{array}$} & \multirow{2}{*}{0.0053} & \multirow{2}{*}{$\mathrm{SS}$} \\
\hline & $\mathrm{NE}$ & 2.2740 & 0.2272 & 0.1312 & & & \\
\hline \multirow[t]{2}{*}{12.5} & E & 6.0430 & 0.3563 & 0.2520 & \multirow{2}{*}{$\begin{array}{l}3.2850 \\
(2.6733 ; 3.8967)\end{array}$} & \multirow{2}{*}{0.0004} & \multirow{2}{*}{ SS } \\
\hline & $\mathrm{NE}$ & 2.7580 & 0.0548 & 0.0316 & & & \\
\hline \multirow[t]{2}{*}{20.3} & E & 11.8083 & 0.6844 & 0.3951 & \multirow{2}{*}{$\begin{array}{l}6.3743 \\
(4.6762 ; 8.0725)\end{array}$} & \multirow{2}{*}{0.0013} & \multirow{2}{*}{ SS } \\
\hline & $\mathrm{NE}$ & 5.4340 & 0.2970 & 0.2100 & & & \\
\hline
\end{tabular}

Abbreviations: CI - 95\% confidence interval of mean of difference, Conc. - concentration of analyte, E enzymatic strip, MD - mean of difference of enzymatic minus non-enzymatic strips, NE - non-enzymatic strip, SD - standard deviation, SEM - standard error of the mean, SS - difference considered to be statistically significant

\section{References}

(1) Hill, H. H., Jr.; Martin, S. J. Pure Appl. Chem. 2002, 74, 2281-2291.

(2) Schwenk, M.; Kluge, S.; Jaroni, H. Toxicol. 2005, 214, 232-248.

(3) Sferopoulos, R. A Review of Chemical Warfare Agent (CWA) Detector Technologies and Commercial-Off-The-Shelf Items, Human Protection and Performance; Division Defence; Science and Technology Organisation: Melbourne, 2009.

(4) Sun, Y.; Ong, K. Y. Detection Technologies for Chemical Warfare Agents and Toxic Vapors, 1st ed.; CRC Press: Boca Raton, 2004.

(5) Hoenig, S. L. In Compendium of Chemical Warfare Agents; Hoenig, S. L., Ed.; Springer: New York, 2007; pp 1-46.

(6) Mackay, D.; Shiu, W. Y.; Ma, K.-C.; Lee, S. C. In Physical-Chemical Properties and Environmental Fate for Organic Chemicals; Mackay, D.; Shiu, W. Y.; Ma, K.-C.; Lee, S. C., Ed.; CRC Press: Boca Raton, 2006; pp 2319-2321.

(7) Pohanish, R. P. Sittig's Handbook of Toxic and Hazardous Chemicals and Carcinogens, 6th ed.; Elsevier: Waltham, 2012.

(8) Drobchenko, S. N.; Isaeva-Ivanova, L. S.; Kleiner, A. R.; Lomakin, A. V.; Kolker, A. R.; Noskin, V. A. Carbohydr. Res. 1993, 241, 189-199.

(9) Iwasaki, I.; Utsumi, S.; Ozawa, T. Bull. Chem. Soc. Jpn. 1952, 25, 226. 